\title{
DETERMINANT ATTRIBUTES VALUED BY BRAZILIAN RETAIL CONSTRUCTION MATERIALS CONSUMERS
}

\author{
ATRIBUTOS DETERMINANTES VALORIZADOS \\ PELOS CONSUMIDORES DO VAREJO BRASILEIRO DE \\ MATERIAIS DE CONSTRUÇÃO
}

Submission: $17 / 04 / 2018$ Accept: 22/03/2019

Nadia Kassouf Pizzinatto ${ }^{1}$ Christiano França da Cunha² Aléssio Bessa Sarquis ${ }^{3}$ Andrea Kassouf Pizzinatto ${ }^{4}$ Evandro Luiz Lopes ${ }^{5}$

\section{ABSTRACT}

This article analyzes the determinant attributes valued by the retail consumer of construction materials in São Paulo State, Brazil, using a survey with 450 consumers from two large retail networks of construction materials in three Brazilian cities testing two hypotheses regarding the differences in attributes valued by the consumes when choosing a point of sale. The Correspondence Analysis (CA) was used to examine relationships of the valued attributes from one city to another. The results showed that there are 45 determinant attributes valued by the consumer, classified into 9 categories (relationship, service, convenience, pricing policy, point of sale, product, services, promotion and brand). The categorization proved to that some categories, for example, convenience, have different meanings in cities with different profiles. Other attributes appreciated by customers were product variety, location of store, personalized service, price, quality of products, and store image. The results of the study contribute to the field by enhancing knowledge of determinant attributes valued in construction materials retail, helping store managers to shape their marketing strategies.

Keywords: Retail marketing, Determinant attributes, Retail of construction materials.

1 Associate Professor of Marketing in the Universidade Metodista de Piracicaba - Universidade Metodista de Piracicaba (UNIMEP), Piracicaba/ SP - Brazil. Post Doctor in Dirección y Mercadotecnia from Universidad Popular Autónoma del Estado de Puebla- UPAE (México). Doctor of Administration from São Paulo School of Business Administration - Getúlio Vargas Foundation (FGV). E-mail: nkp@nadiamarketing.com.br ORCID (Required of all authors): https://orcid.org/0000-0003-1598-6231

2 Professor of Marketing in Program of Master and PhD in Business Administration in the University of Campinas (UNICAMP), Limeira/SP Brazil. Post doctor in Marketing and Transaction Costs in the Institut de la Recherche Agronómique (INRA)/AgroParisTech (France) - Doctor of Business Administration from University of São Paulo (USP). E-mail: chfcunha@unicamp.br

ORCID (Required of all authors): http://orcid.org/0000-0002-2590-3818

3 Professor in the program of master in Business in the Universidade do Sul de Santa Catarina (UNISUL), Florianópolis, Santa Catarina - Brazil Doctor of Administration from University de São Paulo (USP). E-mail: alessio.sarquis@gmail.com. ORCID (Required of all authors): http:// orcid.org/0000-0001-9690-0510

4 Professor of Marketing in the Universidade Metodista de Piracicaba - UNIMEP, Piracicaba/SP - Brazil. Doctor of Administration of Universidade Nove de Julho. E-mail: andreapizzinatto@yahoo.com. ORCID (Required of all authors):https://orcid.org/0000-0001-7088-9114 5 Universidade Nove de Julho and Universidade Federal de São Paulo. São Paulo, São Paulo, Brazil.

Associate Professor of Marketing from Universidade Federal de São Paulo and Doctor of Administration from Universidade Nove de Julho E-mail: elldijo@uol.com.br ; elldijo@uni9.pro.br and evandro.lopes@unifesp.br. ORCID (Required of all authors): https://orcid.org/00000002-2780-4215 


\section{RESUMO}

Este artigo analisa os atributos determinantes valorizados pelo consumidor varejista de materiais de construção no Estado de São Paulo, Brasil, utilizando uma pesquisa com 450 consumidores de duas grandes redes varejistas de materiais de construção em três cidades brasileiras, testando duas hipóteses sobre as diferenças nos atributos valorizados na escolha de um ponto de venda. A Análise de Correspondência (CA) foi usada para examinar as relações dos atributos valorizados de uma cidade para outra. Os resultados mostraram que existem 45 atributos determinantes valorizados pelo consumidor, classificados em 9 categorias (relacionamento, serviço, conveniência, política de preços, ponto de venda, produto, serviços, promoção e marca). A categorização provou que algumas categorias, por exemplo, conveniência, têm significados diferentes em cidades com diferentes perfis. Outros atributos apreciados pelos clientes foram a variedade de produtos, a localização da loja, o serviço personalizado, o preço, a qualidade dos produtos e a imagem da loja. Os resultados do estudo contribuem para o campo, aumentando o conhecimento de atributos determinantes valorizados no varejo de materiais de construção, ajudando os gerentes de lojas a moldar suas estratégias de marketing.

Palavras-Chave: Marketing de varejo, Atributos determinantes, Varejo de materiais de construção.

\section{INTRODUCTION}

The retail marketing management model has undergone changes, from the Transactional Marketing (TM) approach to Relationship Marketing (RM) (Pizzinatto, 2005; Brodie, Coviello, Winklhofer, 2008). TR is based on the 4 Ps strategy (competitive strategies of Product, Price, Place and Promotion), differs from RM, which focuses on the customer, and $\mathrm{n}$ the relationship with him, identifying (proactively and ahead of the competition) his expectations and the determinant attributes he values during the purchase of a good or service (Zakaria et al., 2014).

So, an important strategy is to be aware of the determinant attributes valued by target consumers regarding the store and any similarities or changes in opinion (or perception) of the consumer concerning differences in the profile and geographical location of the target sectors (Nilsson et al., 2015).

Determinant attributes are unique characteristics or aspects of an organization (store), brand or product, considered by the consumer during selection or purchase (Guimarães; Botelho, 2010). Include product, price, location, service, physical environment, relationship and brand image. A consumer's retail experience is influenced (positively or negatively) by the performance of the store's determinant attributes (Granot; Greene; Brashear, 2010). Therefore, retailers need to create an environment in the store that favors interaction with customers and focuses on determinant attributes that have a positive effect on consumer behavior/attitudes. Watanabe, Lima-Filho and Torres (2013), pointed out that, in retail, determinant attributes affect customers' preference, satisfaction and loyalty.

Besides that, the internationalization of companies, propelled by the globalization of the economy, has heightened competition in Brazil and in the retail sector for construction materials the local players has grown rapidly, either by expanding existing chains or by acquiring the businesses of established competitors.

In this competitive environment, retailers need to invest more in managing their relationship with the market, innovation, and customer loyalty. This requires knowledge of the determinant attributes valued by consumers and the way they perceive the attributes of a store (Nor Asiah et al., 2013; Nilsson et al., 2015).

In this context, it was decided that this study would be based on the following research question: Which determinant attributes are valued by Brazilian consumers in the retail market for construction materials? 
This study aims to analyze the determinant attributes valued by the retail consumer of construction materials in São Paulo State, Brazil, specifically those related to the choice of point of sale and examines the differences (and similarities) expressed in the opinions of consumers from the different cities involved in the investigation.

For this purpose, a descriptive study, in the form of a survey, was conducted with 450 consumers in two large retail chains of construction materials in three cities of São Paulo State. These cities, in descending order of size, are São Paulo, Ribeirão Preto and Piracicaba.

The results of the study help to advance academic knowledge of determinant attributes appreciated by consumers in the retailing of construction materials and understand the differences and/ or similarities expressed in the opinions of consumers from different geographical locations (city in the interior or capital city). In managerial terms, the results can help managers of construction materials stores with knowledge of determinant attributes considered important by consumers in the cities in question, especially when it comes to evaluating and formulating marketing strategies.

\section{THE BRAZILIAN RETAIL SECTOR FOR CONSTRUCTION MATERIALS}

In Brazil, retail construction materials organizations are the final link in the market system of the construction sector, including expenditure/investments in the construction, demolition, renovation, expansion and/or improvement of constructions (Receita Federal, 2011). It is responsible for 2,800,000 direct jobs. (IBGE, 2015)

As anticipated, globalization has altered the sector's structure: new operators have entered the market, mainly from Europe. Examples of this competitive transformation in the sector are the arrival of Leroy Merlin (2000), the merger between Madeirense and Conibra (1999 to form C\&C Casa \& Construção), the takeover of Telha Norte by the multinational Saint Globain (2000) and the acquisition of Dicico by the Chilean giant Sodimac (2012). The five largest chains of construction materials distributors are responsible for less than $15 \%$ of sales in the sector (ANAMACO, 2015).

This new competitive environment requires that retailers invest in knowledge of the determinant attributes valued by consumers (Nor Asiah et al., 2013; Nilsson et al., 2015).

Customers are increasingly seeking to solve all their needs at a single point of sale, a concept known as one stop shopping (Dimitrova et al., 2016). High levels of stock, unavailability of goods for immediate purchase and an assortment of products that does not match the consumer profile are serious problems in this sector, which seeks to minimize the impact of these shortcomings through commercial automation which let a better management of time in the efforts of employees (Moriconi Jr. et al., 2006). Due to improve management, the construction materials resale sector shows impressive numbers. There are approximately 133,000 stores selling this type of products, and around $50 \%$ of these stores $(n=64,232)$ are concentrated in the southeast of the country. São Paulo State is home to approximately two thirds of the stores in the region ( $n=35,570)$ (Anamaco, 2015).

\section{DETERMINANT ATTRIBUTES IN THE RETAIL CONTEXT}

In retail, a determinant attribute includes any aspect or characteristic that identifies a certain store or retail brand as described from the viewpoint of the consumer (Woodruff; Gardial, 1996). It can also be understood as any aspect evaluated by the consumer when choosing a store or brand (Guimarães; Botelho, 2010). Zeithaml (1988) classified them as intrinsic cues (related 
to physical property and function, as the location of the store and its physical environment) and extrinsic cues (unrelated to the physical aspects or function, as consumer satisfaction, perceived quality and brand image).

In retail, a purchase experience involves a set of cognitive, affective, emotional, social and physical factors that affect consumer behavior and attitude, influenced by the determinant attributes of the store (Verhoef et al., 2009; Granot; Greene; Brashear, 2010).

The store's image, for example, influences the perceived quality of products and is a source of competitive advantage (Burt; Carralero-Encinas, 2000). The importance of attributes is believed to vary according and the profile or location of the consumer (Treacy; Wiersema, 1993; Odekerken-Schroder et al., 2003; Nilsson et al., 2015).

Thus, the first hypothesis may be stated:

H1: The way determinant attributes are valued in the retailing of construction materials differs according to the location of the consumer.

The marketing literature points out a number of determinant attributes considered by consumers when choosing a store: variety of products (Bearden, 1977), location (Arnold; M.A; Tigert, 1978), publicity/advertising (Mulhern; Leone, 1990), helpful staff (Dabholkar; Thorpe; Rentz, 1995), price (Finn; Louviere, 1996), product quality (Chen; Hu, 2010) and store image (Spinelli; Giraldi, 2004; Helgesen; Havold; Nesset, 2010); price-quality relationship (Treacy and Wiersema,1993); store atmosphere Ballantine, Jack and Parsons,, 2010 and Chamie, Ikeda and Parente (2012).

Thus, the second hypothesis may be stated:

H2: Customers also view the price-quality relationship, convenience and after sales services in a different light.

\section{METHODOLOGY}

The study was a survey with consumers conducted using a questionnaire applied in a field research, with 450 consumers interviewed during a purchase process at three stores in two retail chains of construction materials in three cities. Two cities were in the interior of São Paulo State (Ribeirão Preto and Piracicaba) and the other one was the state capital. One hundred and fifty (150) interviews were conducted in each city.

Specially trained researchers collected the data, and the consumers were approached as they were leaving the checkout after a commercial experience at the selected stores (purchase, exchange, estimate, visit, etc.).

The data collection instrument was a questionnaire with open-ended and closed questions. The questions helped to identify the profile of interactivity between the customer and organization (whether it was a first purchase or what the degree of interactivity was). Questions were also asked about frequency of purchase, the attributes that influenced the choice of store (price, proximity, variety, trust, product quality, opening hours) and the reasons for choosing the other stores. Customers were also asked about their preferred purchase system (self-service or with assistance) and the service they expected.

To analyze the data, qualitative and quantitative research techniques were used. First, using a qualitative technique, the categories of the responses were constructed, regarding the key attributes for consumers when selecting a construction materials retail outlet, as shown in Table 1.

After that two forms of quantitative analysis were used to diagnose the data: a) the Chisquared test (comparing the frequency observed with the frequency expected, calculated based on the interdependence of probabilities between the characteristics to be analyzed, which gen- 
erates a standardized checking measure for the tested hypothesis) (Hoffman, 2006; Hair et. al., 2009); and b) correspondence analysis, which consist in a compositional technique to prepare a perceptual maps based on the association between variables, mostly, originating from a nominal scale, as is the case of the variables analyzed in this study (Hair et al., 2009).

\section{PRESENTATION AND ANALYSIS OF THE RESULTS}

This section contains the presentation and analysis of the results of the research. First, the profile of the research sample is presented, followed by the results of the determinant attributed most valued by consumers when it comes to choosing a retail outlet for construction materials. A total of 450 consumers were interviewed in the three cities, of which $15.11 \%$ were aged 18 to 29 , $51.56 \%$ from 29 to $39,17.78 \%$ from 39 to $49,14.22 \%$ from 49 to 59 and $1.33 \%$ over 59 . Regarding gender, $64.89 \%$ were male and $35.11 \%$ female. Regarding purchase profile, $85.33 \%$ of the interviewees were private buyers and $14.67 \%$ were making a purchase for a company.

The first specific goal of the study was to identify the determinant attributes valued by consumers when choosing a store to purchase construction materials. The results are shown in Table 1, classified into nine categories: relationship, service, convenience, pricing policy, point of sale, product, services, promotion and brand. In all, 45 determinant attributes valued by the consumers were identified, including accessibility, friendship with staff, quality of service, payment facilities, store location, quality of products, delivery service, possibility to buy online and the store's name/ brand. The categories with the more attributes were: convenience ( 9 attributes cited), relationship ( 8 attributes) and product ( 8 attributes). The categories with the fewer attributes were: promotion/ publicity (with only 3 attributes), services ( 2 attributes) and brand (1 attribute).

Table 1 Valued attributes in choice of store, by category

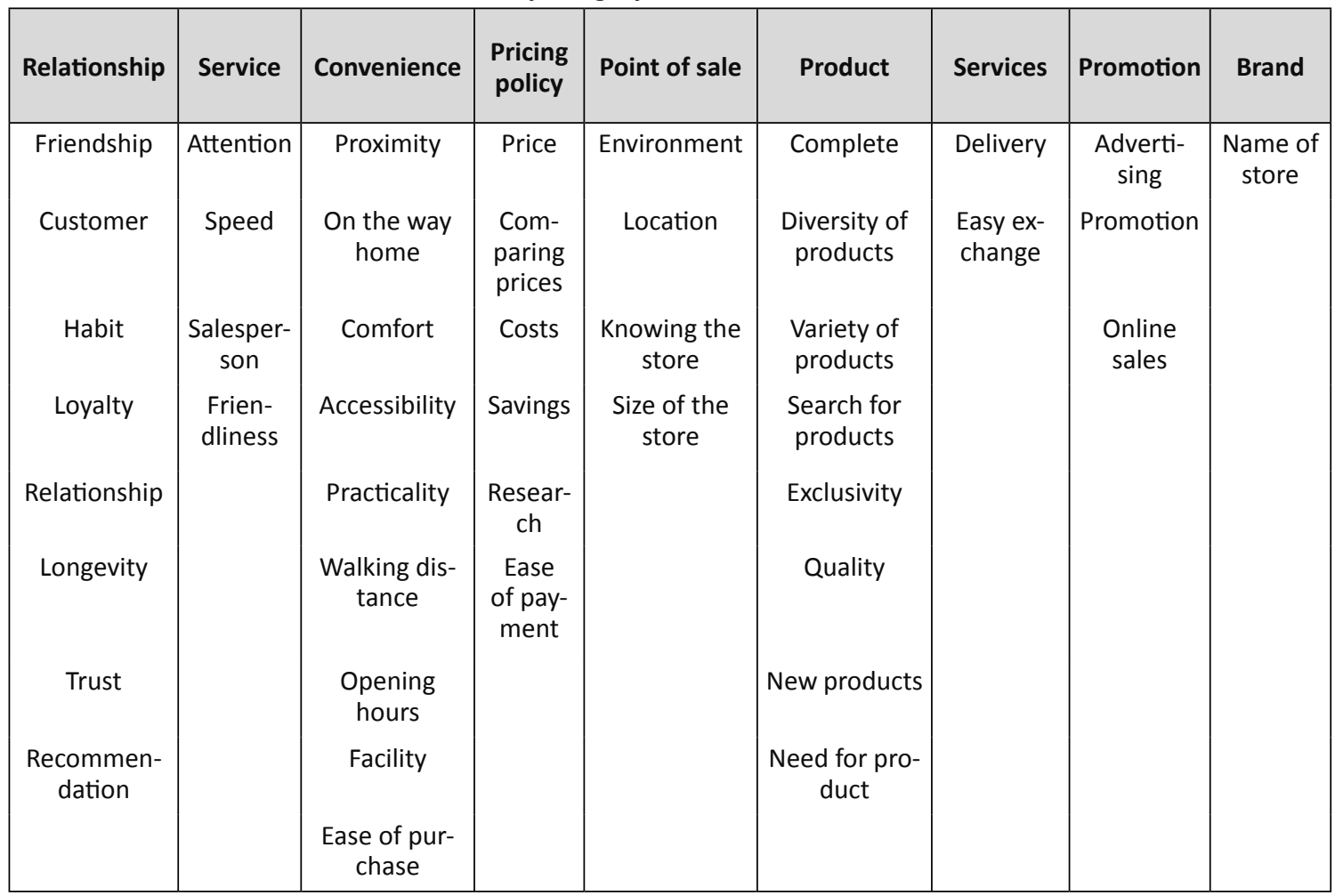

Source: Research results based in Strauss ; Corbin (1998) 
The consumers were asked about their reasons for choosing the store to purchase construction materials. Figure 1 shows the results by category $(n=450)$. The most frequently mentioned categories of reasons by the consumers were convenience (CV), by $51.3 \%$ of the respondents, product (PROD) by $21.7 \%$, and price (PRE) by para $206 \%$. The least cited motive was store name/brand $(\mathrm{BD})$, mentioned by only $0.22 \%$ of the interviewees.

Figure 1. Reasons for choice of store, per category

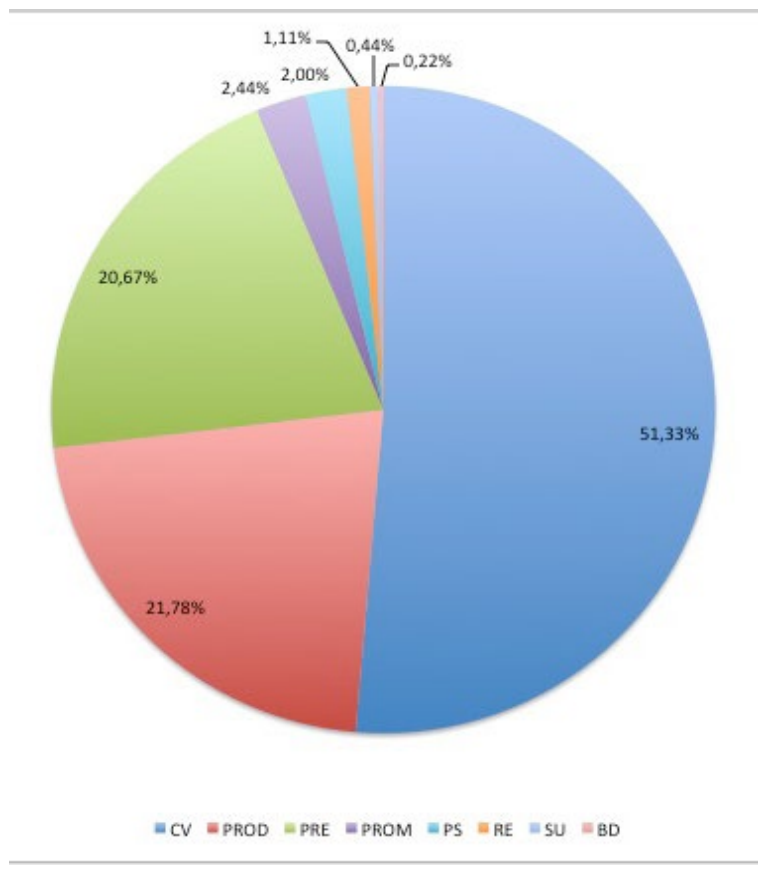

Source: Research results (2016).

The consumers were then asked about the determinant attributes that they appreciated (liked) most in the stores. Figure 2 shows the results of the collected data by category $(n=450)$. The most frequently mentioned categories were product (PROD), mentioned by $34.7 \%$, support (SU), by $26.8 \%$, price (PE), by $19.5 \%$ and convenience (CV), mentioned by $15.5 \%$. The least appreciated categories were services, including home delivery and easy exchange (mentioned by only $0.91 \%$ of the interviewees, point of sale, which includes attributes such as atmosphere, location, knowledge and size of the store (mentioned by $2.44 \%$ of the respondents). These results are deemed relevant and the stores should take them into consideration, especially when it comes to analyzing and formulating their marketing strategies. 
Figure 2. Most appreciated categories of determinant attributes

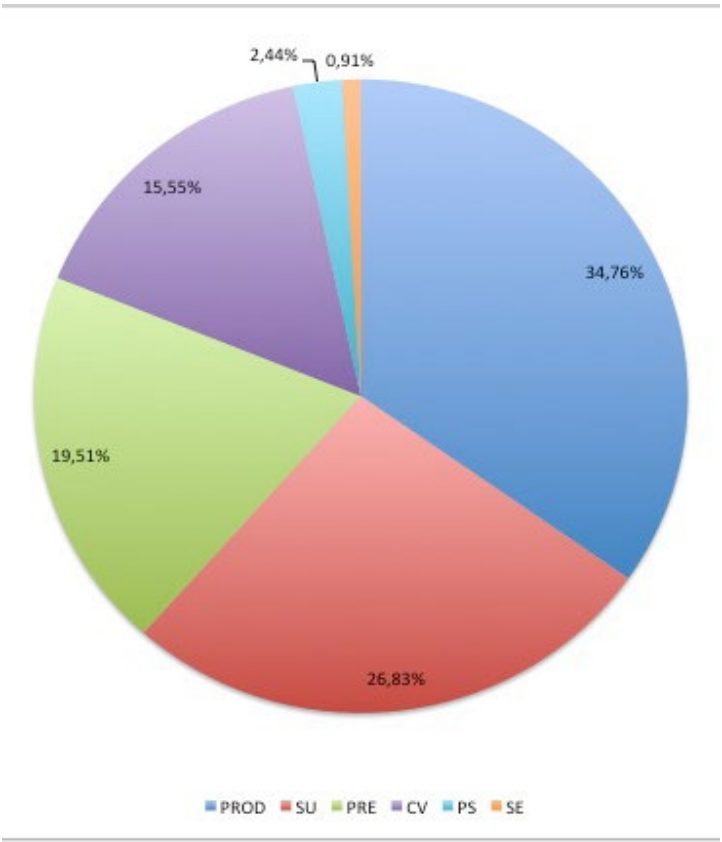

Source: research results (2016).

The data categorization method was applied again to identify the categories of analysis to be considered when evaluating service in the context of construction materials retailers. Table 2 shows the results of the analysis categories and attributes appreciated in terms of service, derived from the affirmative responses of the interviewees. The results show that 13 analysis categories can be used to evaluate service in a construction materials store. The categories are responsiveness, attention, technical knowledge, politeness, kindness, objectivity, respect, friendliness, negotiation, willingness, honesty, delivery and service quality. The categories of analysis with the most determinant attributes were technical knowledge of the attendant ( 7 attributes) and attention and objectivity of the attendant (both with 6 attributes). The categories with the fewest attributes were politeness, respect and delivery, all of which had only one attribute.

Table 2 - Categories of analysis and highly valued attributes with regard to Service.

\begin{tabular}{|c|c|}
\hline Categories & Most Appreciated attributes \\
\hline Responsiveness & Agility of salespeople; speed; promptness \\
\hline Attention & Attentive staff; dedication; patience; interest; cordiality; orientation \\
\hline $\begin{array}{l}\text { Technical know- } \\
\text { ledge }\end{array}$ & $\begin{array}{l}\text { Knowledge; preparation; good information; competence; novelties; show diversity; } \\
\text { experience }\end{array}$ \\
\hline Politeness & Politeness \\
\hline Kindness & Kindness \\
\hline Objectivity & Objectivity; clarity; efficiency; not speak too much; simplicity; not pressure customers \\
\hline Respect & Respect \\
\hline Friendliness & Friendliness; charisma; charm the customer; courtesy; likeability \\
\hline Negotiation & Good price alternative; price; variety of prices \\
\hline Willingness & Willingness; willingness to help; pro-activity; willingness to sell \\
\hline Honesty & Honesty; truth; sincerity \\
\hline Delivery & Punctual delivery \\
\hline Service quality & Good service; quality of service; services \\
\hline
\end{tabular}
Source: Research results (2016) 
Finally, the most appreciated determinant attributes in the Service category, according to the interviewees $(n=450)$, are shown in Figure 3. The results show that the most appreciated attributes are (ATCN), in the opinion of $29.3 \%$ of the respondents, technical knowledge (TK), for $27.5 \%$, availability (AVA), for $14 \%$ and responsiveness (RESP), for $12.6 \%$. The least appreciated are negotiation (NEG), kindness (KIND), service quality (QLT_SU) and objectivity (OBJ), each accounting for fewer than $2.5 \%$ of the respondents' citations.

Figure 3. Key attributes of Service category

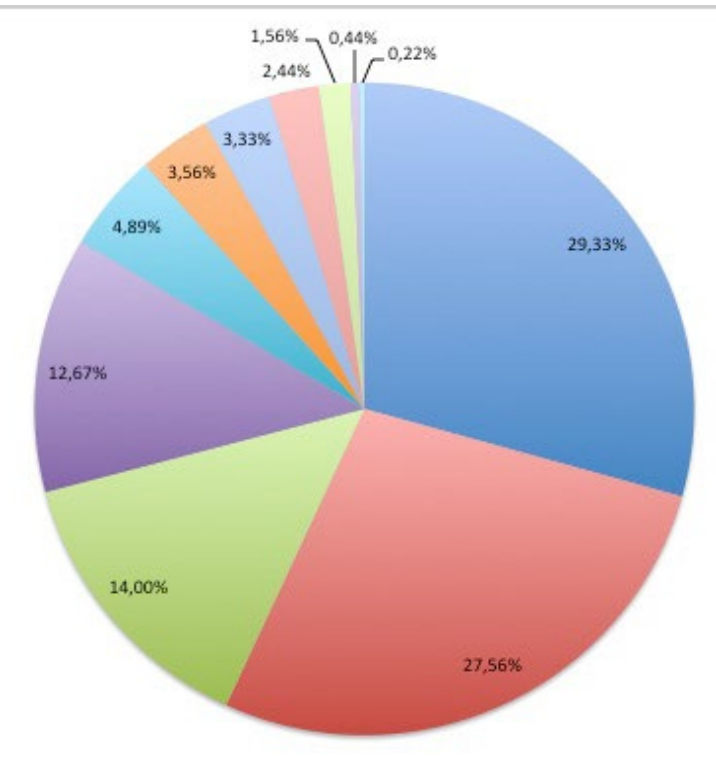

$=$ ATCN $=$ TK $=$ AVA $=$ RESP $=$ HON $=$ SIMP $=$ EDU $=$ OBJ $=$ QLT_SU $=$ KIND $=$ NEG

Source: research results (2016).

\subsection{Results of the comparative analysis of appreciated attributes by city}

The second specific goal of the present study was to examine the different opinions of the consumers in the three cities. For this purpose, the inferential statistics test Chi-squared $(x 2)$ was performed to identify the two most appreciated determinant attributes in the opinion of the respondents from the greatest distribution differences of the Chi-squared.

Table 3 shows the results for each city (São Paulo, Ribeirão Preto and Piracicaba), with regard to the most highly appreciated and second most appreciated attributes and the respective categories, as shown in Table 1. The Chi-squared test was applied to arrive at the data in Table 3. The Chi-squared test works with expected frequencies (based on the independence of factors, in this case the city and the attributes) and observed frequencies (those obtained in the study) (Hoffman, 2002). All the attributes in Table 3 had a higher observed frequency than expected, which indicates the rejection of the independence of the factors under study (priority of attributes and the city in question). Therefore, for example, in the case of São Paulo, proximity (convenience) was highlighted, because 30 respondents were expected to mention this as an important attribute in the case of independence of the factors under study. However, 72 interviewees mentioned it as a more important attribute in their purchases, meaning a Chi-square value of 58.8 and a rejection of this independence hypothesis of factors at a level of significance of $1 \%$. 
The most appreciated categories of attributes were convenience (the most appreciated in São Paulo and Ribeirão; the second most appreciated in Piracicaba), products (first place in Piracicaba, second place in São Paulo) and price (second place in Ribeirão Preto). It should also be noted that the consumers of construction materials interviewed in São Paulo and Piracicaba placed greater value on convenience and product, while consumers in Ribeirão Preto valued convenience and price.

Table 3 - Most highly ranked attributes per city and their respective categories

\begin{tabular}{|c|c|c|}
\hline \multirow[t]{2}{*}{ City } & \multicolumn{2}{|c|}{ Highest ranked attributes } \\
\hline & Most appreciated attribute/category & 2nd most appreciated attribute/category \\
\hline São Paulo & Proximity (Convenience) ${ }^{* * *}$ & Product diversity (Products) ${ }^{* * *}$ \\
\hline Ribeirão Preto & Extended opening hours (Convenience) ${ }^{* * *}$ & Savings/price and pricing policy (Price) ${ }^{* * *}$ \\
\hline Piracicaba & Variety of products (Products) ${ }^{* * *}$ & Accessibility (Convenience) ${ }^{* * *}$ \\
\hline
\end{tabular}

Source: Research results (2016)

Note: ${ }^{* * *}$ Level of significance of $1 \%$

The statistical technique Correspondence Analysis (CA) was then used to examine possible relationships of the valued attributes (or categories of attributes) from one city to another, either in terms of the reasons for choosing a store, categories of attributes more appreciated by consumers, attributes more representative of the service category or attributes more representative of the convenience category.

The results of the Correspondence Analysis (CA) for reasons to choose a particular store are shown in Figure $\mathbf{4}$ for each city. As shown in the green circle, in Piracicaba, convenience (CV) and price (PRE) were the main reasons for the choice of a construction materials store, as was also the case in São Paulo, as shown in the blue circle. In Ribeirão Preto, the most important reasons for this choice were products (PROD) and relationship (RE), as shown in the red circle.

Figure 4. Reason for choice of store to purchase goods by city.

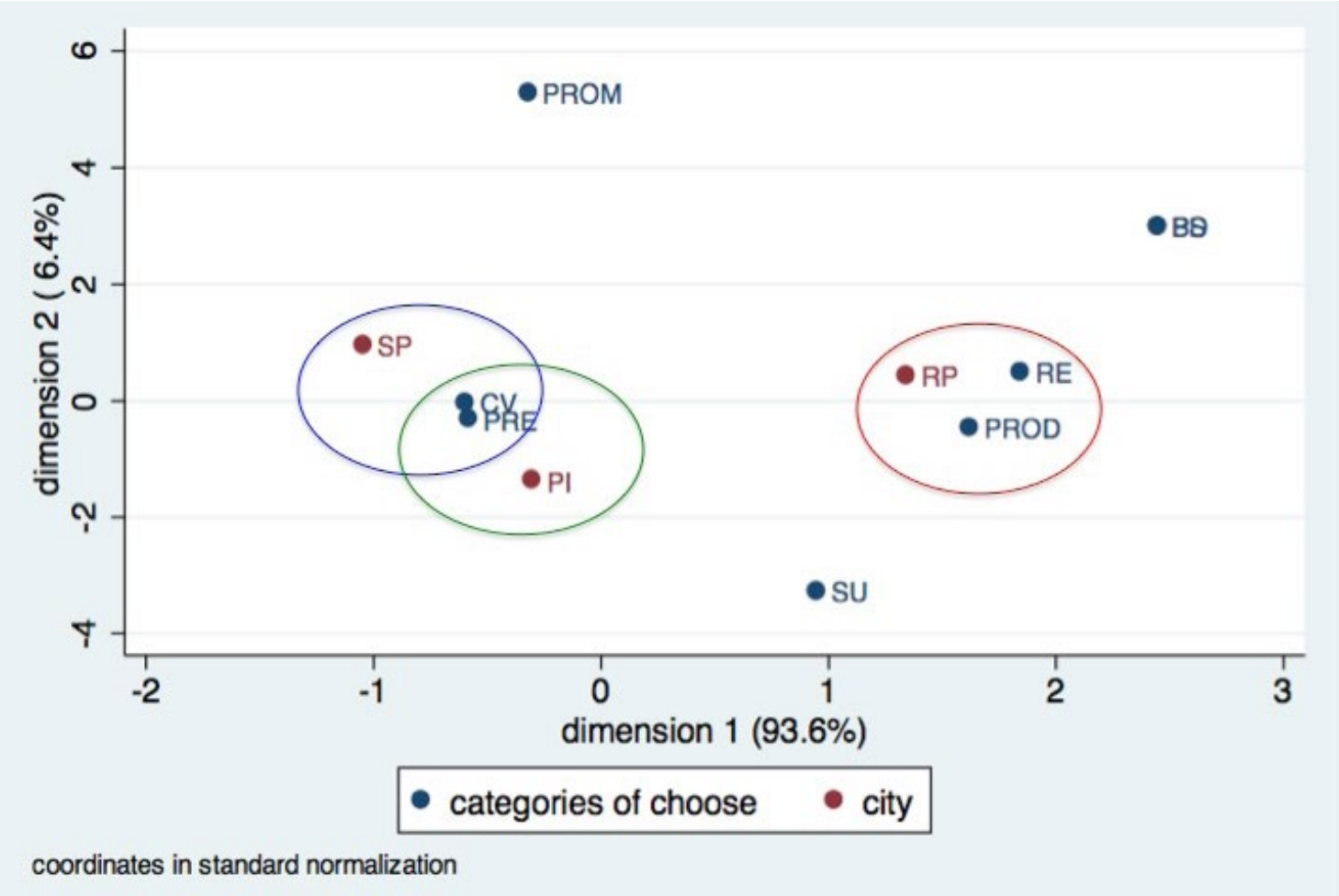

Source: Research results (2016)

Rev. AdM. UFSM, SANTA MARIA, V. 13, NÚMERo 3, P. 501-516, 2020 
The results of the Correspondence Analysis (CA) technique are shown in Figure 5 for the most appreciated categories of attributes by the respondents in each city. The results revealed in a graph with two estimated dimensions and three clusters of the most appreciated categories, one for each city. Dimension 1, with explanatory power for $91 \%$ of the variance, was called Intangible Attributes, since support (SU) was the category with the highest positive value on the scale (1.57) and point of sale (PS) had the highest negative value (-1.86). Dimension 2, with explanatory power of $9 \%$, was called Influence of People on Attributes, with service (SE) being the category with the highest positive value on the scale (6.80) and convenience (CV) with the most negative value $(-1,27)$. The results also showed that convenience $(C V)$ and product (PROD) were the most appreciated categories of attributes by consumers in Piracicaba (green circle). Product (PROD) and price (PRE) were the most appreciated categories by consumers in Ribeirão Preto (red circle). Support (SU) was the most appreciated category in São Paulo (blue circle).

Figure 5. Categories of attributes most appreciated by consumers in each city.

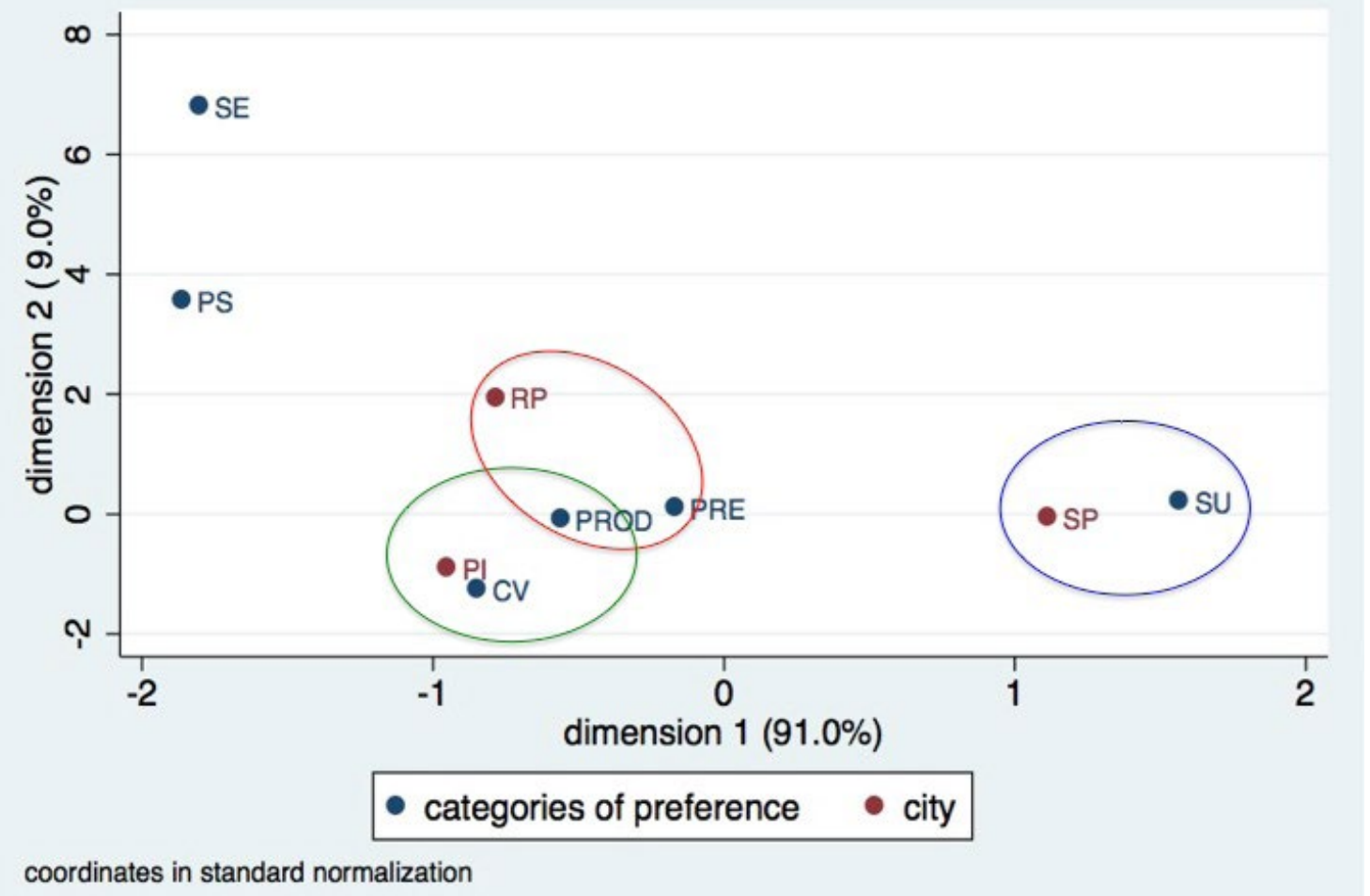

Source: Research results (2016)

When evaluating service in retail, there may be differences in consumers' perceptions of what constitutes good service. Thus, Correspondence Analysis (CA) was used to gauge the key attributes of Service in each city. The results are shown in Figure 6, a graph with two estimated dimensions. The data also show three clusters of attributes for Service, one for each city. Dimension 1, with explanatory power for $80.8 \%$ of the variance, was called Prompt Service, as it includes aspects of responsiveness (1.18) and availability (1.69), with the highest positive values, the most representative attributes for the category. Meanwhile, honesty (-1.08), objectivity $(-0.99)$ and attention $(-0.96)$ were the most negative values on the scale, the least representative 
attributes of the category according to the consumers. Dimension 2, with explanatory power of $19 \%$, was called Subjectivity in Service, as kindness (3.56), quality of service (3.56) and negotiation $(3,56)$ had the highest positive values on the scale, while honesty $(-2.92)$ and objectivity $(-0.76)$ had the most negative values.

Figure 6 - Key attributes of the Service category by city.

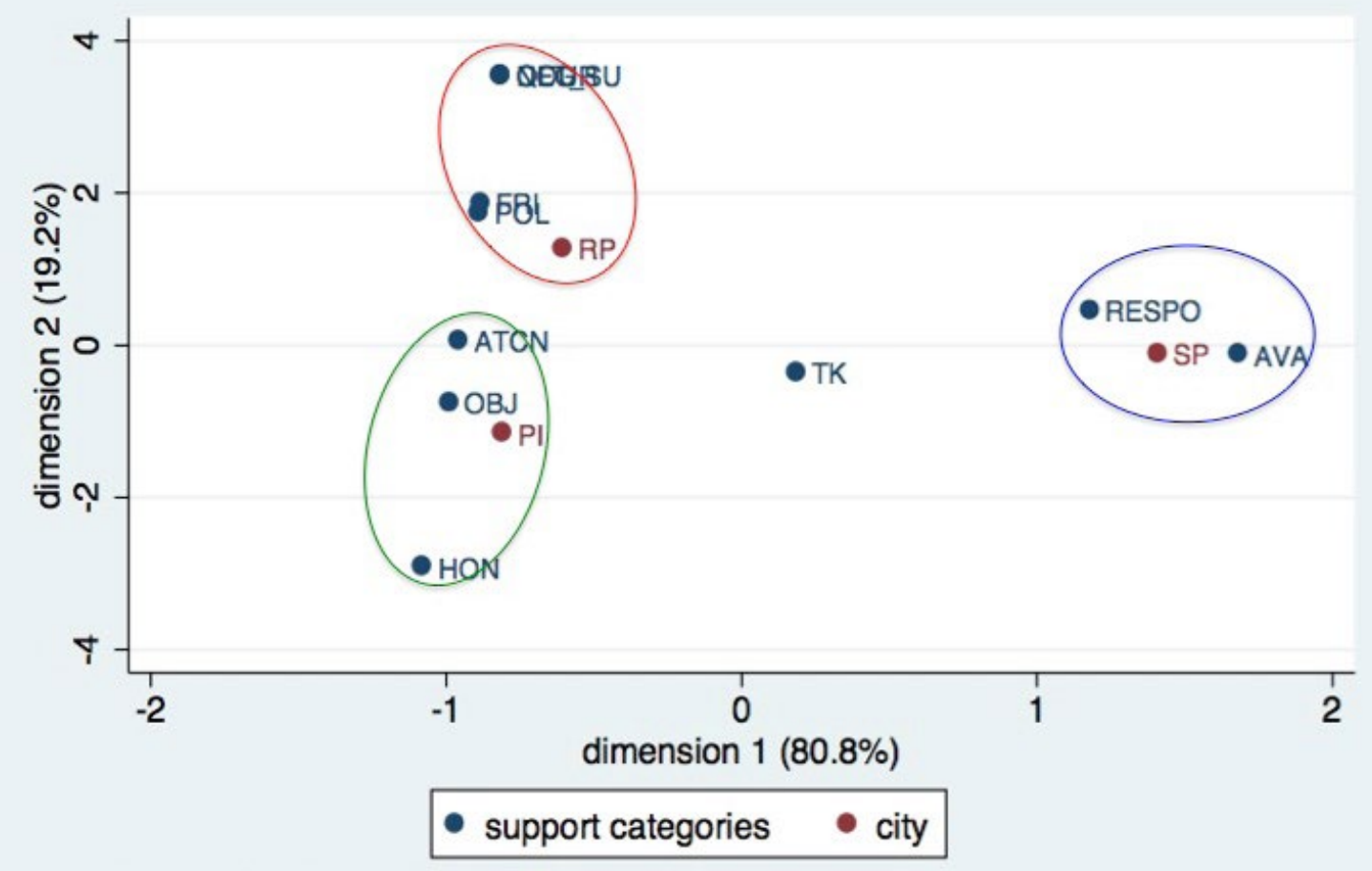

coordinates in standard normalization

Source: results of research at the three stores

Figure 6 also shows that according to consumers in Piracicaba, the key determinant attributes of service are objectivity (OBJ), attention (ATCN) and honesty (HON) (green circle). In Ribeirão Preto, the key attributes for service are friendliness (FRI), politeness (POL), quality of service (QLT_AT), negotiation (NEG) and kindness (KIND) (red circle). For consumers in São Paulo, the key attributes of service are responsiveness (RESPO) and availability (AVA) (blue circle).

Finally, Figure 7 shows the results of the Correspondence Analysis for the key attributes of the convenience category for each city, with three different clusters of key attributes for convenience (one per city) and a graph with two estimated dimensions. Dimension 1, with explanatory power for $57.9 \%$ of the variance, was called Saving Time, with attributes such as speed, ease of purchase, practicality and more flexible opening hours, reflecting consumers' concerns over saving time. Dimension 2, with explanatory power of $42 \%$, was called Spatial Location, with attributes such as on the way home, accessibility and walking distance (which all had positive values on the scale). Practicality and longer opening hours had negative values. These attributes emphasize customers' concerns with the spatial location of the retail outlet. 


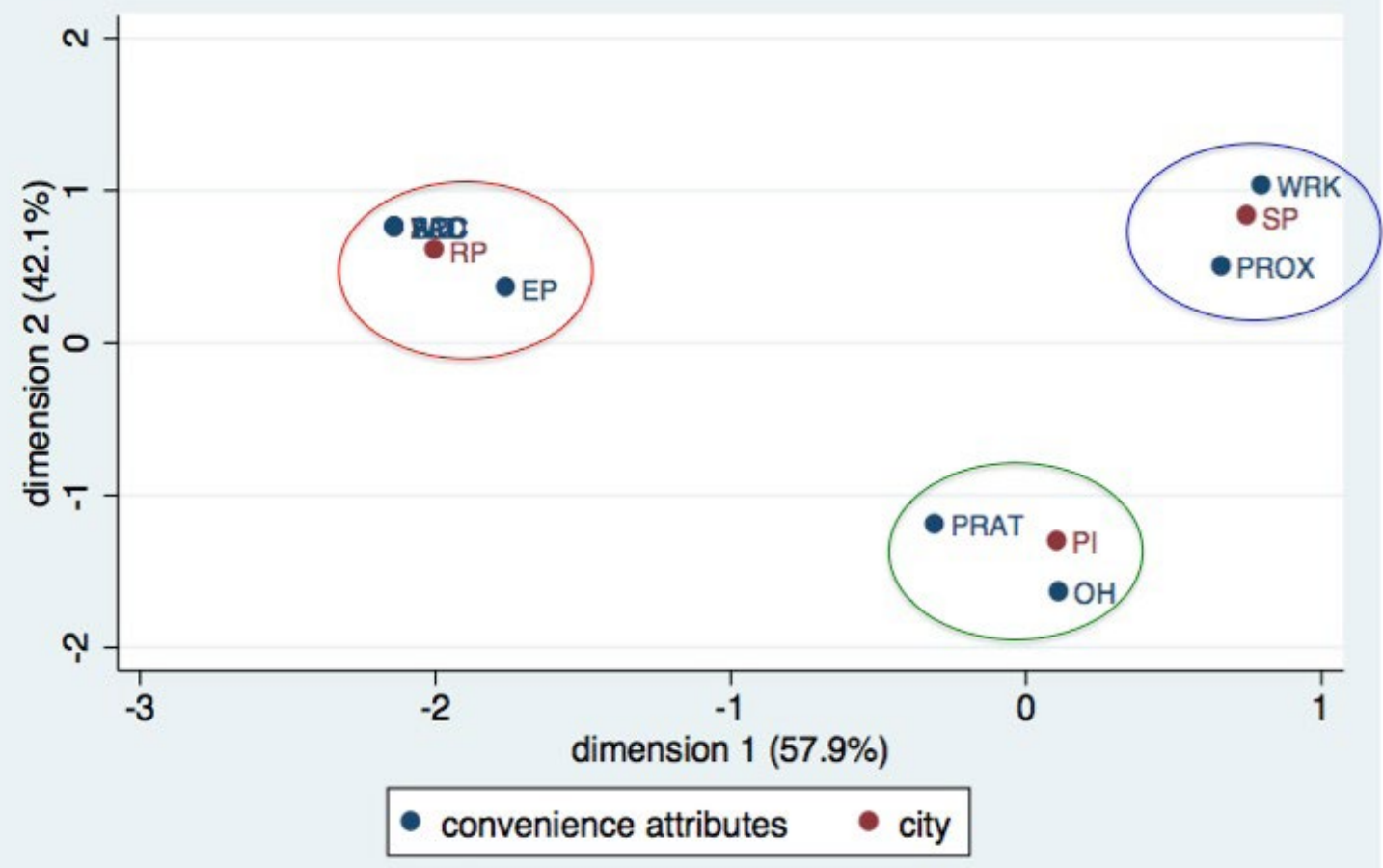

coordinates in standard normalization

Source: Research results (2016)

Figure 7 also shows that the key attributes for consumers in Piracicaba (PI) in terms of convenience were opening hours $(\mathrm{OH})$ and practicality (PRA) (green circle). For consumers in Ribeirão Preto (RP), the key attributes of convenience were ease of purchase (EP), speed (SPD), accessibility (ACC) and within walking distance (WD), (red circle). The key attributes for consumers in the city of São Paulo/SP were proximity (PROX) and being on the way home from work (WRK) (blue circle).

\subsection{Discussion of the results}

The results in Figure 4 show the non-rejection of Hypothesis 1, as the attributes regarding the reasons for choosing a store may vary from city to city. While consumers in São Paulo and Piracicaba base their choice of store on attributes in the categories of price and convenience, customers in Ribeirão Preto place greater value on attributes in the relationship and product categories described in Table 1.

The categorization of the determinant attributes identified in the study proved to be appropriate, as it helped to demonstrate that a category, e.g., convenience, has different meanings in cities with different profiles, such as São Paulo and Ribeirão Preto, as shown in Figure 7. The figure shows that in São Paulo where, due to the size of the city, people have to save time on the purchase process, convenience can mean that the point of sale is near the customer's home or workplace. However, for consumers in the interior, convenience means longer opening hours, as the stores where the survey was conducted in Piracicaba and Ribeirão Preto are located in a shopping mall, away from a heavy traffic flow, allowing easier access for consumers. 
The conclusion of the results presented here is the non-rejection of Hypothesis 2, as there are different determinant attributes that affect customers' options regarding a specific retail outlet to purchase construction materials.

Therefore, the results corroborate the findings of some authors (Treacy; Wiersema, 1993, Odekerken-Schroder et al., 2003 and Nilsson et al., 2015) (H1) and the non-rejection of H2, regarding attributes appreciated by customers being product variety (Bearden, 1977), location of store (Arnold; MA; Tigert, 1978), personalized service (Dabholkar; Thorpe; Rentz, 1995), price (Finn; Louviere, 1996), quality of products (Chen; Hu, 2010) and store image (Spinelli; Giraldi, 2004; Helgesen; Havold; Nesset, 2010. Treacy; Wiersema (1993).

\section{CONCLUSION}

This study, supported by quantitative data research techniques (Chi-squared test (Hoffmann, 2002)) and Correspondence Analysis (Hair et al, 2005)) associated with qualitative research techniques, such as the creation of categories of analysis of the attributes mentioned by the interviewees and listed in Table 1, contributes to the field of marketing management for retailers of construction materials. The study also strengthens the position of the theoretical framework that supports the study, as explained in the discussion. The results showed many similarities between the three cities in question, mainly in relation to one category of attributes that was highly valued in all three cities, convenience, which was listed as the most important in São Paulo and Ribeirão Preto, and came second place in Piracicaba. However, despite this similarity, a more in-depth study showed significant differences in the opinions of the interviewees. For example, to residents of São Paulo, convenience means being close to their home or workplace, while people in Piracicaba understand convenience as longer opening hours and/or practicality when making a purchase.

This is also the case of the service attribute, which is valued in all three cities, but for different reasons and with different individual values. The results suggest that a marketing manager should adopt a personalized sales strategy, training employees how to approach customers, as the results show that customers like swift service, with emphasis on responsiveness and availability. Thus, training should focus on practical examples, observing simulations of sales techniques.

This shows that even though there are worldwide, national or regional trends in the appreciation of attributes that can result in more successful customer service, it is also important to observe the direction of marketing strategies, which should be customized and refined to suit local habits. For instance, what constitutes convenience for one group of consumers may not necessarily be the same for another group in another city.

A suggestion for future studies would be to conduct the same research in other cities to observe which attributes considered valuable in this study are interpreted similarly or differently in other locations, and which other attributes are appreciated in other cities. Furthermore, the study could be replicated in other types of retail establishments and other sectors to provide better knowledge of the attributes appreciated by customers of these organizations. 


\section{REFERENCES}

ANAMACO (Associação Nacional dos Comerciantes de Materials de Construção. Available in: www.anamaco.com.br Acess: october 3th. 2016;

ARNOLD, S.; MA, S.; TIGERT, D. A comparative analysis of determinant attributes in retail store selection. Advances in Consumer Research, v. 5, n. 1, p. 663-667, 1978.

BALLANTINE, P.; JACK, R.; PARSONS, A. Atmospheric cues and their effect on the hedonic retail experience. International Journal of Retail \& Distribution Management, v. 38, n. 8, p. 641653, 2010.

BEARDEN, W. Determinant attributes of store patronage-downtown versus outlying shopping centers. Journal of Retailing, v. 53, n. 2, p. 15-33, 1977.

BRODIE, Roderick J. COVIELLO, Nicole E. WINKLHOFER Heidi. Contemporary Marketing Practices research program: a review of the first decade. The Journal of Business \& Industrial Marketing. Santa Barbara: 2008. Vol. 23, Iss. 2, p. 84-94.

BURT, S.; CARRALERO-ENCINAS, J. The role of store image in retail internationalisation. International Marketing Review, v. 17, n. 4/5, p. 433-453, 2000.

CHAMIE, B.; IKEDA, A.; PARENTE, J. Atmosfera de loja como um elemento da estratégia varejista. Revista Administração em Diálogo, v.14, n.1, p. 01-31, 2012.

CHEN, P.; HU, H. How determinant attributes of service quality influence customer-perceived value: an empirical investigation of the Australian coffee outlet industry. International Journal of Contemporary Hospitality Management, v. 22, n. 4, p. 535-551, 2010.

DABHOLKAR, P.; THORPE, D.; RENTZ, J. A measure of service quality for retail stores: scale development and validation. Journal of the Academy of Marketing Science, v. 24, n. 1, p. 3-16, 1995.

DIMITROVA, B. V.; ROSENBLOOM, B.; ANDRAS, T. L. The Impact of National Culture on Retail Structure. In: Celebrating America's Pastimes: Baseball, Hot Dogs, Apple Pie and Marketing?. Springer International Publishing, 2016. p. 735-736.

FINN, A.; LOUVIERE, J. Shopping center image, consideration, and choice: anchor store contribution. Journal of Business Research, v. 35, n. 3, p. 241-251, 1996.

GRANOT, E.; GREENE, H.; BRASHEAR, T. Female consumers: decision-making in brand-driven retail. Journal of Business Research, v. 63, n. 8, p. 801-808, 2010.

GUIMARÃES, K.; NETTO, M.; LIRA, R. Qualidade de serviços no varejo: um estudo realizado em uma empresa do setor farmacêutico de Campos dos Goytacazes. Humanas Sociais \& Aplicadas, v. 4, n. 11, p. 47-60, 2014.

GUIMARÃES, R.; BOTELHO, D. Atributos relevantes na escolha de lojas de conveniência. Revista Eletrônica de Administração, v. 16, n. 1, p. 224-245, 2010.

HELGESEN, O.; HAVOLD, J.; NESSET, E. Impacts of store and chain on the quality-satisfactionloyalty process in petrol retailing. Journal of Retailing and Consumer Services, v. 17, p. 109-118, 2010. 
HAIR, J. F. et al. Análise multivariada de dados. Bookman Editora: Porto Alegre, 2009.

HOFFMANN, R. Estatística para economistas. Pioneira : São Paulo, 2006.

IBGE (Brazilian Institute of Geography and Statistics). Institutional website. Avalaible in: www. ibge.gov.br Acessed in: October 03th, 2016.

Moriconi, C., Jr., Pacheco, F. A., Flório, M. T., Tuma, R. L., \& Perez, T. H.. Prevenção de perdas no varejo de materiais para construção civil. In J. R. Oliveira Filho (Org.), O varejo de materials de construção no Brasil - mecanismos operacionais (Cap. 2. pp. 34-52). São Paulo: Ed. DVS. 2006.

MULHERN, F.; LEONE, R. Retail promotional advertising: do the number of deal items and size of deal discounts affect store performance? Journal of Business Research, v. 21, n. 3, p. 179194, 1990.

NILSSON, E.; GÄRLING, T.; MARELL, A.; NORDVALL, A. Importance ratings of grocery store attributes. International Journal of Retail \& Distribution Management, v. 43, n. 1, p. 6391, 2015.

NOR ASIAH, O.; ANIZA CHE, WEL.; ABD AZIZ, N.; SHAH ALAM, S. Investigating the structural relationship between loyalty programme service quality, satisfaction and loyalty for retail loyalty programmes: evidence from Malaysia. Measuring Business Excellence, v. 17, n. 1, p. 33-50, 2013.

ODEKERKEN-CSHRODER, G.; OUWERSLOOT, H.; LEMMINK, J.; SEMEIJN J. Consumer's trade-off between relationship, service, package and price: an empirical study in the car industry. European Journal of Marketing, v. 37, n. 1, p. 219-242, 2003.

PIZZINATTO, N.K., Marketing focado na cadeia de clientes. São Paulo: Atlas, 2005.

SPINELLI, P.; GIRALDI, J. Analise teórica e empírica da imagem de loja e da marca própria varejista: implicações estratégicas. Cadernos de Pesquisas em Administração, v. 11, n. 4, p. 59-73, 2004.

STRAUSS, A.; CORBIN, J., Pesquisa Qualitativa: técnicas e procedimentos para o desenvolvimento de teoria fundamentada.Porto Alegre: Bookman,1998.

TREACY, M.; WIERSEMA, F. Customer intimacy and other value disciplines. Harvard Business Review, v. 71, n. 1, p. 84-93, 1993.

VERHOEF, C.; LEMONB, K.; PARASURAMAN, A.; ROGGEVEEND, A.; TISIROS, M.; SCHLESINGER, L. Customer experience creation: determinants, dinamics and management strategies. Journal of Retailing, v. 85, n. 1, p. 31-41, 2009.

WATANABE, E.; LIMA-FILHO, D.; TORRES, C. Atributos de imagem da loja e a satisfação de clientes em supermercados de Campo Grande-MS. Revista Brasileira de Marketing, v. 12, n. 4, p. 85-107, 2013.

WOODRUFF, R.; GARDIAL, S. Know your customer: new approaches to understanding customer value and satisfaction. Cambridge: Blackwell, 1996. 
ZAKARIA, I.; RAHMAN, B.; OTHMAN, A.; YUNUS, N.; DZULKIPLI, M.; OSMAN, M. The relationship between loyalty program, customer satisfaction and customer loyalty in retail industry: a case study. Procedia-Social and Behavioral Sciences, v. 129, p. 23-30, 2014.

ZEITHMAL, V. Consumer perceptions of price, quality, and value: a means - end model and synthesis of evidence. Journal of Marketing, v. 52, n. 3, p. 2-22, 1988.

\section{Contribution of authors}

\begin{tabular}{|c|c|c|c|c|c|}
\hline Contribution & [Author 1] & [Author 2] & [Author 3] & [Author 4] & [Author 5] \\
\hline 1. Definition of research problem & $\mathrm{v}$ & $\mathrm{v}$ & & & \\
\hline $\begin{array}{l}\text { 2. Development of hypotheses or research } \\
\text { questions (empirical studies) }\end{array}$ & $\mathrm{v}$ & $\mathrm{v}$ & & & \\
\hline $\begin{array}{l}\text { 3. Development of theoretical propositions } \\
\text { (theoretical work) }\end{array}$ & $\mathrm{v}$ & $\mathrm{v}$ & & & \\
\hline 4. Theoretical foundation / Literature review & $\mathrm{V}$ & 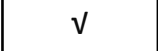 & 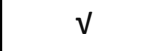 & $\sqrt{ }$ & $\mathrm{v}$ \\
\hline 5. Definition of methodological procedures & $\mathrm{V}$ & $\mathrm{v}$ & $\mathrm{v}$ & $\mathrm{v}$ & $\mathrm{v}$ \\
\hline 6. Data collection & $\mathrm{V}$ & $\mathrm{v}$ & $\mathrm{v}$ & $\mathrm{v}$ & $\mathrm{V}$ \\
\hline 7. Statistical analysis & $\mathrm{v}$ & $\mathrm{v}$ & $\mathrm{v}$ & $\mathrm{v}$ & $\mathrm{v}$ \\
\hline 8. Analysis and interpretation of data & $\mathrm{v}$ & $\mathrm{v}$ & $\mathrm{v}$ & $\mathrm{v}$ & $\mathrm{v}$ \\
\hline 9. Critical revision of the manuscript & $\mathrm{v}$ & $\mathrm{v}$ & $\mathrm{v}$ & $\mathrm{v}$ & $\mathrm{v}$ \\
\hline 10. Manuscript writing & $\mathrm{v}$ & $\mathrm{v}$ & $\mathrm{v}$ & $\mathrm{v}$ & $\mathrm{v}$ \\
\hline 11. Other (please specify) & & & & & \\
\hline
\end{tabular}

